\author{
Agné Kulbytė \\ ๑ https://orcid.org/0000-0001-9074-9995 \\ Vilnius Academy of Arts \\ agne.kulbyte@vda.It
}

\title{
THE PAINTER AS A PROPHET TURNED TOWARD THE PAST
}

\begin{abstract}
This article deals with the problem of recognition of the romantic model of memory in contemporary art and theory, which emerged after the so-called "narrative turn". The ambiguous philosophical statement by Friedrich Schlegel is taken as a key-phrase for the analysis. It unlocks the character of the artist's (painter's) visions and ambitions settled at the beginning of the 19th century. A constitutive role of active memorization in the process of romantic creativity required commemoration to be the central aim of artistic expression. It is also a rudiment of popular contemporary artistic strategies. Imaginative narratives and subjective myths spread in numerous, inertial, visual metaphors. Are they overcoming the romantic intention or extending it? Following the insights of Andreas Huyssen, Franklin Rudolf Ankersmit and other researches, this analysis tries to touch upon a huge transformation in the understanding of memory and emphasises that there are important abandoned aspects close to the highly psychologized version of romantic memory, which lie in the philosophical-theological interpretations of romanticism. They do not allow us to reduce memory to a "theme" or an "object" of an artistic project. The author highlights the influence of the power of memory upon the creation of form and the inner anticipation of meanings. Without this positive and idealized understanding of memory (emphasized by romantic philosophies), pictorial expression would lose its uniqueness.
\end{abstract}

Keywords: romanticism, postromanticism, memory, representation, narrative, painting, historicity.

Romantic memory ${ }^{1}$ is one of the essential concepts to express subjective experience in relation to the philosophy of imagination and the subconscious. In reflecting on it, the existential aspects that are important for the concept of

1 The term romantic memory became fixed in the middle of the 20th century in academic studies on Romanticism, mainly in literary theories (Geoffrey Hartmann, Frank Kermode), among other essential concepts defining romantic thinking: romantic imagination or romantic love. Since the 1980s, these concepts have become ingrained in philosophical and culturological studies as multiple metaphors. 
modern subjectivity, such as temporality, identity or finality, become apparent. In the most recent studies on memory, the category of romantic memory is often reborn in opposition to the postulates of poststructuralism, in advocating for the so-called definition of individual memory. Interestingly, after the so-called "narrative turn", the meanings of romantic memory took on new connotations (they relate to the concepts of grandeur, apocalypse, trauma, ritual, testimony and others ${ }^{2}$ ). These are subjective, ephemeral, fragmentary postromantic manifestations of consciousness that have already moved away from the provisions of romantic metaphysics, or reproduced them in a negative form. Separated from subjective experience, memory is also perceived as a deconstructive force and even romanticism itself becomes as a kind of a cultural obsession or "disease". Despite this difference, we can assume that it is the romantic aspects of the perception of memory in the current debate that highlight the emerging image of historical time, as if filling a "gap" in its narrative. As opposed to opinions held by the advocates of the concept of antihistorical, "empty" or "structural" memory, romantic memory is rather a substitute for a historical narrative, synonymous with this category.

The dominance of the topic of memory in the discussions on contemporary painting is often based on the belief that the past cannot be reproduced, and that language and creative material in themselves overrule the subject, dissolving it in the creation of new semantic orders and narratives. At first glance, it is reminiscent of the romantic ideas of unrepresentativeness. It is associated with the spontaneous, involuntary power of memory and its philosophical concept based on the platonic self-awareness of the soul and specific romantic archetheology. However, in the processes of contemporary painting, one can see the tension between the narrative (discursive) and expressive (lyrical) perception of memory, whose contradictory interactions and descriptions encourage the analysis of the problem of historical comprehension.

Indeed, there is too little reflection on the significance of the cultural shift for painting, while the fact that it is simply automatically linked to the possibilities offered by new media obeys the prevailing theoretical and literary narratives in the cultural environment. All the more so as some researchers are by

2 Kerwin Lee Klein consistently discusses the transformation of these concepts in his review of contemporary memory research (K. L. Klein, On the Emergence of Memory in Historical Discourse, in: "Representations", 2000, no. 69).

3 In her article (Memory Studies: For and Against, 2008), Susannah Radstone criticizes the hegemony of the category of trauma as a factor forcing nihilistic treatment of memory and Christopher Lasch does the same with reference to the category of nostalgia in his book (The True and Only Heaven: Progress and Its Critics, 1991); L. K. Klein critically reflects on the "therapeutic function" of memory as a sequence of the superficial amalgamation of memory and new historicism (K. L. Klein, op. cit., p. 129). 
now alluding to the crisis of memory research, the narrowing of this field of thought, or its becoming standardized. ${ }^{3}$ So, how much can romantic memory be a substitute for historical imagination? When does the connection between memory and history become fiction and illusion, and where are its limits?

\section{Between the archetypes and authentic visions}

Romantic visions and dreams are inseparable from the theological conception of the world and history: the longing for the magnificent past of mankind, back to Biblical times, seems to find room in the concept of the so-called Great Memory ${ }^{4}$ vision. There exists an awareness of the timeless, invariable and constant world which is intuitively discovered inside each individual. The capacity for such a priori remembering lies even in the 18th century, in Immanuel's Kant's notion of creative imagination and in the Romantics' considerations on the Absolute (philosophy of Novalis, Schlegel or Schelling). Great Memory works as a synonym for the sacred or archetypical sphere which inspires us to preserve our own origins and ideals, and to protect them from extinction, oblivion and vulgarization.

Kant's transcendental reflection is the "ability to remember" of the creative imagination that he describes as the mysterious power of consciousness in action which, as if hidden from the mind, is capable of projecting inner, pre-experiential content (also approaching the experience of the sublime). Thus, the presumption of ideality operating in the consciousness of the subject a priori, as well as its pursuit, are perceived as transcending the possibilities of subjective cognition and the ordinary power of contemplation of reality, and allowing for the recognition of the divine plan operating in reality. In the philosophy of Romanticism, this memory-related term acquires the names of universal nostalgia, infinite longing, lack and ideal past (merging into the plan of operation and development of the historical spirit as described later by Friedrich Hegel). Thus, Friedrich Schlegel's interpretation of the "finite self" and the infinite ratio reveals the schema of the fragment and the universe: only the comprehension of finality allows one to grasp the changing reality, as well as to fit in the vision of the historical trajectory; finality also varies - it always tends

4 In romantic interpretations, the metaphor of Great Memory often acts as the equivalent of the Great Narrative. Such generalized naming of memory comes from theological interpretations of history, where the course of history is understood as having a transcendent purpose (e.g. in the philosophy of Saint Augustine). Memory coincides with the metaphysical concept of the meaning of history; when detached from temporal events, it gives meaning to history and also foresees future perspectives. This rendering of memory in romantic philosophy is markedly different from the utopian and futuristic interpretations of progress offered by Enlightenment philosophers. 
to infinity; "finite" forms lie in memory - it is already "I" carried away by the flow of time. Thus, the awareness of infinity lies in the entity itself - the image of integrity with the whole, created by memory. The time scale identified by Schlegel seems to be reversed: the "past" is the "future" because it transcends the present, filling it with meaning and mystery.

In texts by Friedrich Schlegel, the reflection of the subject (the "finite self") is basically connected with one's own past - the biographical narrative. One's own past is worshiped, it provides a counterweight, a sense of purpose and serves as the basis for identity. Thanks to memory, the present seems to always have its "other" side, which is regarded as a trace of harmony or a distant whole. ${ }^{5}$ Therefore, the perception of memory as a personalized power becomes extremely important; it helps us to perceive finality, to see a certain image of reality detained in the flow of time, to foresee its spread. Therefore, Romantics exaggerate spontaneous glimpses of insight which help us, though for a short time, to overcome a huge loss of time and which destroy fictions. Particularly, the artistic images and metaphors of memory reflect the desire to combine immutable and temporary areas of experience.

Romantics call memory the most important "concern of the soul" or the inner "awareness of the soul". They associate this existentially important effort to recover the past with the need to constantly refresh and observe memories, and turn it into an endeavour of artistic creativity. However, the experience of reality in the romantic image remains generalized, since it is related to the power of nostalgia ${ }^{6}$ pervading all artworks. The total vision of romantic art is coloured by these nostalgic themes and images of memory, and has traits of melancholy, pathos, exaltation, rebellion or criticism. All this arises from the desire provided by the longing to recover the primordial harmony. Works of art often express this state of longing in the form of passive contemplation. As the artists of early Romanticism perceived it, the source of their creative work is the unconscious, mysterious state of the psychic world. In visions and artistic expressions, it appears as the search for the "other reality", "the reality of memory" (Emanuel Swedenborg, Guston Bachelard) or the contemplation of the native land as a symbolic, special form of autobiographical awareness

5 In Athenaeum Fragments (1798), in the words of fragment no. 80, Friedrich Schlegel mentions the power of memory to combine fragments of experience, as well as traces of "cultural heritage": "The historian is a prophet turned towards the past" (F. Schlegel, Friedrich Schlegel's Lucinde and the Fragments, transl. P. Firchow, Minnesota University Press, Minneapolis 1971, p. 170). By the way, at this point, he reflects on the relativity of cognition and seeks to describe the very style of "writing in fragments".

6 Nostalgia and memory are obviously interlinked, but, it seems, the practise of nostalgia is much more connected with the searches of mimetic art. 
(Oscar Milosz, Adam Mickiewicz). ${ }^{7}$ Paintings also speak about this hidden unity of visions, of contemplating infiniteness, which is endowed with a sense of melancholia, mourning or a fictional split from reality, neither remembering the past, nor anticipating the future.

This romantic structure of memory has also taken effect in the intersubjective sphere which defines the contemporary concept of subjectivity. In his book L'Âme romantique et le Rêve (1937), ${ }^{8}$ the Swiss author Albert Béguin interprets the category of Great Memory in a characteristic way, seeing romantic meanings in spiritualist metaphysics and in the philosophy of personalism from Maine de Biran to Henry Bergson. Here, "pure memory" based on the concept of individuality is in operation, linking the phenomenological phases of time (past-present-future) into an authentic experience. Moreover, memory does not just have a biblical meaning here, but is also associated with the myth of the blueprint of language as the source of poetic power in itself. Thus, it is basically perceived within the framework of a specific romantic, anti-historical discourse, expressing both the individuality and the historical authenticity of the agent. ${ }^{9}$ Even when the romantic worldview has no direct theological landmarks, the archetypal, mystical or subconscious layers which are associated with memory processes, remain the most important ones in such a worldview.

We can notice that the scope of romantic memory is of delineated amplitude. Despite the fact that memory is able to create a vision of entirety and is linked to the sphere of eternity, it may manifest itself only when it is faced with a temporal reality, without which it would be an empty category. But this is an important argument in support of the theological concept of memory, which makes it possible to distinguish the understanding of memory from negative occasionalism. In Béguin's words, it cannot be dissociated from the origin of the "creative spirit" as "vital energy", moved or projected beyond exact time limits. ${ }^{10}$ Romantic thinking finds it by any means impossible to separate memory from other components of experience, to clarify it or absolutize it. In this way, a premonition is preserved in the romantic vision, i.e. none of the spora-

7 See K. Trybuś, Biografia romantyczna jako forma pamięci, in: Biografie romantycznych poetów, ed. Z. Trojanowiczowa, J. Borowczyk, Wydawnictwo Poznańskiego Towarzystwa Przyjaciół Nauk, Poznań 2007.

8 A. Béguin, L'Âme romantique et le Rêve, José Corti, Paris 1991.

9 Such an approach to Romanticism can be based on a critique of the modern concept of time and "historicism" that was set up later. Thomas Pfau reconsiders Walter Benjamin's research as follows: "nineteenth-century Historicism was ignoring the distinction between historical and Messianic time" (Th. Pfau, Mourning Modernity: Classical Antiquity, Romantic Theory, and Elegiac Form, in: The Oxford Handbook of the Elegy, ed. K. Weisman, Oxford University Press, Oxford 2010, p. 549). 
dic details such as dreams, experiences or resemblances that have got stuck in memory, represent the spread of the viable reality. So, they are connected with spontaneous experience occurring prior to reflection and appearing before an unpredictably occurring event.

The internal dialectics paradoxically permeating the relationship with reality are typical of romantic thinking: a Romantic finds serenity only when feeling longing and a lack of a larger entirety. This also causes a dilemma which is typical of the total understanding of modern subjectivity, i.e. an aspiration to combine the invariable and temporary areas of experience. A Romantic grasps his identity when swinging between the conscious and subconscious, rationality and sensitivity, tradition and happenstance. So, for a romantic artist, painting from memory is more real than painting from life and he or she sees in reality that which he sees in his/her imagination and memory. "If I thought of painting the spring, I could only do it in the winter", Jean-Jacque Rousseau remarked. The painter's relationship with the work is purely personal and uninterrupted (as can be seen in Turner's inner "directing" of the picture space and the combination of different perspectives, or in the romantic landscapes of the picturesque genre that combine travel memories and fantasies evoked by distant lands). In other words, they embody the invisible content of memory without the help of a plot or any literary implications. Later modern and post-romantic art has been deliberately creating the past time projection. The following categories of timelessness and pure expressivity have become essential: turning to primitive cultures, a primeval state, exotic images or deep-seated remembrances of childhood. The image, visible from the distance of memory, seems to be better understood, have acquired a more real form, greater impact and power, and have opened up a new, hitherto unhighlighted aspect of reality.

\section{The romantic argument for certainty}

It is no coincidence that the concepts of memory and re-presentation in romantic art are, in principle, related. Representation works from the power of remembering. Modernist figurativity also proves this: a painting is an image created by consciousness rather than by copying individual impressions of reality. So, creative effort includes the meaning of reproduction, exposition and, especially, of repetition and visualization of the fact of reality or event. As Sussane Langer reflected, memory creates a virtual history (an essential image of human experience) and, specifically, makes these events "distinguishable". ${ }^{11}$

11 S. K. Langer, Feeling and Form. A Theory of Art, Charles Scribner's Sons, New York 1953, p. $262-263$. 
Once memory and the spheres of artistic creativity have been linked, the inevitable questions arise: is the "memory artefact" obtained by artistic means really authentic? Is any memorializing action bound by experiencing the present? Does the choice of means of expression determine the visualization and vision of the past in a certain way? Is the creative action itself distinguished by its power to remember, when a live evidence of reality is preserved, until nothing is overestimated and emphasized in the flow of images and recollections? In many cases, it would seem that artworks themselves are only the manifestations of imagination and reflections provided by memory about a reality that is distant in time. The fiction-reality contradiction is already inherent in the creative process: the need to think over the real experience encourages searching for its traces in reality and the flow of internal reflections immerses one into the world of imagination or dream.

However, can all things which are sensed and experienced in reality turn into so-called "forms of memory"? From the romantic point of view, it is as if the fictions that are being created by artistic means experience the challenge that is imposed by memory. Without this feeling, it would only turn into artificial fiction and lose the dimension of existential expression.

The specificity of the romantic concept is contained in the fact that memory is identified with the so-called feeling of "moral certainty". It ties the creative process because it requires certain responsibility for the things which turn into memory and have become the "memory events" for the type of recollections that are projected in the internal space of consciousness. According to Romantics, it cannot be identified by mind or confirmed by any information or material image; it can be understood as a deliberate internal effort to get rid of the image's ambiguity, to avoid the reversibility of possible implications. So, memory has a twofold function: it binds the aspiration to bring back a moment in the flow of time and, at the same time, encourages the endless reproducibility and rushes of memories. Hence, by refreshing the remembered images, it itself re-interprets and creates them.

As Frances Ferguson shows in her study on Wordsworth, the images produced by this power are not the same as those arising from the simple ability to remember: "the things which we haven't experienced can influence the things which we have really experienced". ${ }^{12}$ She says that images which are encouraged and produced by memory itself can be painful, traumatic, haunting and, on the contrary, they are also capable of curing, consoling and saving. As regards the

12 F. Ferguson, Romantic Memory, in: Studies in Romanticism, Vol. 35, No. 4, Winter 1996, p. 513. (An important association here is that with contemporary reflections on memory: that "which we haven't experienced" can also be understood as erased or left in silence). 
former, memory protects us against unexpected images and imaginings which are not related to the first impression of experience. It resembles the feeling of guilt because of our forgetfulness of precious and most important recollections which constantly lie in wait because of their inconstancy and estrangement (after all, everything that is forgotten becomes alien, unrecognisable and lifeless to the Romantic). As for the latter, it provides serenity because it is realized that everything that has settled in memory is invariable and irrevocable, that the first experience is an unreal fact surpassing human perception, the breath of grace. ${ }^{13}$ Such moments remaining in memory serve as certain starting points for internal reflections which we revert to, seeking to take hold of the spontaneous flow of images, to re-watch it and to protect it from mechanical processes and stimuli.

According to the romantic conception, memory does not comprise mechanically accumulated archives or an artificially idealized sphere - it is necessary for maintaining living contact with reality and works as the constant revision and reflection of actions and experiences, and is equivalent to the effort to recognize the intimate aesthetic truth. In other words, things which cannot be forgotten or which, despite the impact they produced, have been forgotten, remain in memory. And then a separate fact, like daylight that has burst from the past, does not look accidental; thus, it is necessary to name it and to give form to it. The things that remain in the internal "shrine of memory" (Ferguson's term) are remembered; they constantly come to the surface, but not with the purpose to annul the facts of reality or to recall them ("memory comes not to record the past but to represent the power of seeing a past that one didn't experience at the time of its occurrence" ${ }^{14}$ ).

As a matter of fact, it is possible to define the romantic relationship with reality as a constant process of discovery, forgetfulness and regaining of vision. Memory strengthens imagination in its peculiar way by stretching a bridge between the existing reality and the reality that is being created. Thus, the living relationship with the relic of the historical past is always important in the romantic vision. A romantic artist always returns to his unforgettable places - to the same monuments, symbols and relics, and fixes his emotional experience by continuous dedications, elegies, in memoriam, letters and diaries (also expressed in painted forms). In this way, the romantic vision that is being constantly contemplated via the prism of memory, paradoxically acquires some influencing reality. The memory which synthesizes daily experience and opens a higher dimension for experiencing time, constantly confirms the sensation

13 Ibid., p. 525.

14 Ibid., p. 533. 
of reality. A certain basis is formed by the subjective power of imagination, without which romantic visions would seem vague.

The authenticity of a historical fact seems to be easily transferred to the fiction of memory, but it is the aspiration of romantic art - the highest possibility of revealing this "identity". A number of literary and artistic elegiac genres developed over the romantic period can be associated with this concept. They seem to merge the narrative form with pure lyrical expression: in other words, we can see a synthesis of factuality and timelessness in them. Interestingly, we can also notice the pattern of such thinking in figurative language itself. For example, a series of oeuvres which were created on the in memoriam theme in the $20^{\text {th }}$ century and presently, in which reflections of the past and present time are interlaced in a peculiar way, can be called a leitmotif of the development of romantic memory (from allegories by Gustav Courbet, to still-lives by Vincent van Gogh and commemoration compositions by Pablo Picasso). The romantic concept turns in memoriam into an elegy with ambiguous symbolism. The feeling of "moral certainty" does not allow us to fall into the cycles of traumatic images of the past.

In fact, in spite of the multiplicity of meanings and the playfulness of images, romantic paintings usually retain meaningful purity. The artistic truth revealed in a piece is perceived as the givenness of memory (the expectation to make a "moral decision" can also be projected as a question addressed to the viewer). Thus, the treatment of memory that is personalized and related to the theological entirety surpasses the empirical and psychological interpretation. It negates the perception of the memory as an automatically working "receptacle of images" or as a simple empirical and incognizable factor. Our experience of reality and the forms that are being represented seem to be unrelated at first glance, even in the most expressive pictorial reflection (e.g. in abstract painting). The memory image dictates "something of its own", activates the randomness which brings back and resembles the presentiment of the whole. ${ }^{15}$ Just as in the structure of cognition, a distinctive interrelation of the past-present-future opens up in the work of art - virtual memory is at work here. Such a poetic piece does not necessarily have to be created from the author's memories or does not have to project the other person's story (such strategy is typical of the narrow narrative method and of mimetic structures), but it is able

15 The concept of memory, based on inner reflection and awareness of one's actions and thoughts, is sometimes referred to as an anti-romantic trend. For example, theories on the cult of genius suggest that imagination and passion are controlled forces that serve to create specific images or a method of creative work. However, we can also understand this paradoxical assertion in the light of romantic ideals, where true fiction seems more plausible than reality. Distrust in memory, as well as in "pure image" in artistic oeuvre, stems from the forgetting of the romantic "ethical imperative" connected with deeper understanding of individuality. 
to create an illusion of the timeless present (a "total effect"). So, the expressive lyrical reflection ${ }^{16}$ itself is an attempt to actualize history, as if self-reflection was performed by the artistic form itself (in a non-discursive form). Each time, it revives and restores to life events from the stream of passing time. The power of contemplation concealed in memory is always related to developing the yet unseen, faded episode and to its new exposure, and direct emotional experience. At the same time, poetic reality is very definite, autobiographical reality which cannot be fully decoded, as it is an unrecognizable projection each time: "The whole creation in lyric is an awareness of a subjective experience and the tense of subjectivity is the "timeless" present. This kind of poetry has the "closed" character of the mnemonic mode, without the historical fixity that outward events bestow on real memories; it is in the "historical projection" without chronology." 17

The elegiac, meditative form of romantic works automatically points to such an undeclared task of the creation of memory - the possibility of returning each time to the same images and phenomena, and experiencing them anew. Longing for what "used to be" brings us closer to idealism, even though it is unattainable. ${ }^{18}$ It is the distance of longing that gives birth to poetic power - images of reality, as if it had the power of "prophecy". This preserves the essential task of the work of art. As grammatical structures of a language themselves create the impression of an "immutable" reality in verbal art ${ }^{19}$, spatial constructions convey the nonlinear time experience in painting, the feeling of completeness and integrity, and changes of form (regardless of whether specific or physical elements are depicted). However, here as well, one relies on the circumstance that it is as if the image emerges from memory, which turns the event into the present. Paradoxically, the gap from historicity is a more profound way of realizing it, while memory affects the presentational and articulate forms of expression.

16 The romantic concepts of lyrical expression or poetic image are used as general terms here. In particular, they emphasize the proximity of painting to potery. As F. Schlegel described in fragment no. 116: "romantic poetry is a progressive, universal poetry"; "it embraces everything that is purely poetic, from the greatest systems of art"; "the romantic kind of poetry is still in the state of becoming" (F. Schlegel, Athenaeum Fragments, op. cit., p. 175).

17 S. K. Langer, op. cit., p. 268.

18 It is longing for the artistic ideals and masterpieces of ancient or Renaissance art. Interestingly, when not identified with the concept of the "cultural past", these ideals are seen as an aspiration - in the future.

19 The past tense as the grammatical form of the narration inspires a sense of historicity in the poetic piece, whereas the present tense directly expresses the process of contemplation (S. K. Langer, op. cit., p. 260). 


\section{Post-romantic projections}

Can we assume that a contemporary painter would understand Friedrich Schlegel's metaphor of the relationship between the past and future in exactly the same way as one would in the romantic era? Or does it simply apply literally to the contemporary virtual reality? After all, the idea of inverted space-time is reflected in our lifetime and contemporary painting, too. In addition, we can recognize the transformed romantic archetheological concept of memory in the contemporary theories of cosmic becoming (especially under the influence of Nietzsche's ideas), as well as in the postmodern concepts of timeless, antihistorical memory (whose current equivalent could be global memoryscapes or images of collective memory suitable for postmodern plurality). Similarly, in theories of painting, the concepts of empty events (Lyotard), or mute monuments (Deleuze) that constantly perpetuate the sense of the present, attract us as the forces of becoming, of inhuman structures. ${ }^{20}$

Post-romanticism is a phenomenon which convinces us that Romanticism can also live in a blend with a completely opposite ideology - postmodernism (associated with the discourses of art as production and commodification of art). This demonstrates that images that used to express Romanticism as ideology of individuality hybridize easily and transform themselves into conceptual, intellectual artistic solutions. In painting, these varieties are more related to conceptual rethinking of the national identity, historical and mythological images or theology, etc. Artistic strategies mask the gap between personhood and universality. Authors are still looking for new ways of figurative expression - extending the boundaries of painting, but it is rare for the literary and figurative side of images to reach synthesis, so images are simply projected and reproduced. Romantics' sentiments (dictatorship of memory) turn into an object of chronicle registering.

A deeper glance at the conception of romantic memory allows us to feel the difference here: without the metaphysical references, only by enjoying limitless associations that are provided by the internal reflection, romantic memory is transformed into the opposite forms and substitutes. Here the postmodern insights by Andreas Huyssen seems felicitous: amnesia starts to work not like the memory antipode, but like "the other" that is inalienable from it, like a part of itself. Eventually, the memory becomes a synonym not for nostalgia, but for the postmodern pastiche: "In that dystopian vision of a high-tech future,

20 J.-F. Lyotard defines the space which is revealed by painting as the time in which the painting exists, whereas he applies the category of "the event" to describing the processes of representation - which is absolutely sufficient in itself, just presents what it is and what is unrepresentable (J.-F. Lyotard, The Inhuman. Reflections on Time, transl. G. Bennington, R. Bowbly, Polity Press, Cambridge 1991, p. 93). 
amnesia would no longer be part of the dialectic of memory and forgetting. It will be its radical other. It will have sealed the very forgetting of memory itself: nothing to remember, nothing to forget". ${ }^{21}$ It also turns into a peculiar test for contemporary painting - into a question about the meaning of creative ideas. The romantically understood imperative "to remember" emerges every time, seeking representation of the "yet unseen" episode of the lost past time. It may also mean an aspiration for higher ideals - an effort to join the mentioned time chain. Without this impulse, the desire to "see the past" turns into thirst for the simulation of images. Huyssen's insight shows that memory in such visual works transforms into a totally different theme - not into the revelation of image and expression, but into the development of ostensibly autobiographical lines. It seems it is easier to revive the past and to reveal the world of visions by forgetting one or another part of the past, or by manipulating with clichés and stereotypes.

The fusion of memory and historicity, the illusion of their synthesis - these topics have been ingrained in postmodernity. Still, the emphasis on the visionary power of memory makes us wonder: are we coming to anti-historical, antihumanistic formalism? Contemporary artists build so-called "small narratives" detached from any tradition, as if memory was only "a natural feature of the landscape". ${ }^{22}$ Just as historicity is created in artificial ways, so artistic narratives can only tell "restricted" subjective stories and reflect on the present that includes the "vague" spaces of the past and the future.

The proponents of narrative historiography often aesthetize strategies for comprehending the past. When defining the position of a historian (who is identified with the artist), Franklin Rudolf Ankersmit terms this phenomenon as "privatization" (or "alienation"): a piece of collective history that is defined for the purpose of scientific or artistic research, is interpreted by the subject in his/her own way, without taking into account the former or existing meaningful landmarks or guideposts. ${ }^{23}$ Certainly, it is often the case that these attempts destroy fictitious or imposed schemes. However, these strategies themselves more often turn into the creation of new fictions (artists/painters boldly call their subjective projects a "reconstruction of reality") or, in the romantic aspiration to record, into attempts to universalize feelings by preserving signs. These sign-pictures become important not for general experience, but as attempts to allocate one's own field of meanings. "The postmodernist past is, therefore, a past that is at the same time more concrete and more alien than was the past of disciplinary historical writing". ${ }^{24}$

21 A. Huyssen, Twilight Memories. Making Time in a Culture of Amnesia, Routledge, London 1995, p. 9 .

22 K. L. Klein, op. cit., p. 131.

23 F. R. Ankersmit, Historical Representation, Stanford University Press, Stanford 2001, pp. 153-154.

24 Ibid., p. 155. 
There is a large number of such artistic declarations and aspirations to rehabilitate or to fill in the gaps anew in contemporary painting. It is a paradox that the remnants of popular historical, social and political narratives are used in the paintings that strive for the consolidation of subjectivism. They predominate by their negative form (for example, when chasing recollections and certain symbols of power, they are constantly manipulated; when totally impersonal codes are chosen for subjective articulation, it is as if they are satisfied with accidental images, alien things and clichés ${ }^{25}$ ). Romantic sentiments (the dictates of memory) are converted into a flow of subjective expressions and determinations. Technologies also have the power to "personalize" those planes and forces that would otherwise remain foreign, uncontrollable, and inaccessible to the agent, but at the same time they provoke artificial feelings. One gets satisfied with the destruction of general interpretations and criticism, but not with the development and comprehension of one's own interpretations.

The new constructions and expressions of memory usually only shield the radically changed trend of romantic interpretation. It seemingly remains unnoticed and, to be more precise, no attention is paid to the fact that the effect of this phenomenon is quite opposite to what it seems to be at first sight: the individualized vision is consolidated and trusted; however, it is not a washed-away fragment of the stereotyped presentation which is condemned to be swiftly remade. The forms of identity that are constructed with the help of artistic images endlessly expand subjective autobiographical memory totally beyond recognition (what used to be private has now become public). However, these forms act like single fictions, which does not necessarily have to be related to the basis of wholeness that is provided by memory. The collage of memory images that is not subordinate to the subject's will and mind, and that has been formed from different experience and information layers, ruins the intimate, internal structure of the experience of time; neither the sequence of time, nor the starting points or the feeling of historicity remain. Thus, it can be stated that "to privatize" a piece of the so-called memory investigation field, it is only necessary to re-translate the meanings. There remains neither anxiety because of their loss, nor anguish because of their realization.

Frank Ankersmith seems to too easily replace the so-called "narrative logic" with representation and with the so-called concept of the sublime historical experience, where the category of the past has been annulled or dissolved. It also relates to equating the facts of history with aesthetic creative work. Some

25 In the German language, the neologism ostalgie is a popular metaphor for historical memory to name recollections that are typical of daily life rather than traumatic ones. It is these memories that are often manipulated as a stylistic means in the formation of the plot and composition of paintings. 
scholars (Christopher Lasch or Thomas Pfau) criticize such a specific manifestation of romantic aesthetics as the total prevalence of nostalgia in contemporary art. According to Pfau, elegiac and nostalgic intonation manifests itself in the most unexpected forms of exaltation, rebellion, criticism, pathos and melancholy, while in the pursuit of pure contemplation, it finds itself on the verge of ecstasy or destruction. The specific romantic feeling is provoked by the pressure of conflicting forces, which, by this time, is associated with the transformations of modernity. ${ }^{26}$ However, the romantic view of the past, permeated by "mourning mysticism", the genres of dedication and memorialization in art have taken on an inert form (even Anselm Kiefer"s "burned landscapes" prove this ambiguity).

The modernist genre of in memoriam was primarily associated with national and patriotic works intended for honoring, exalting or building the image of a universally significant event or personality. Romantic memorialization was characterized by injecting an aesthetic moment into a historical sequence, rather than contrasting one's own constructions of the past. Such romantic dedications often also had a clear and declarative charge of political thought. In the current works, we can notice a certain aesthetic exaltation which manifests itself not only in the search for form, but precisely in the repetition of symbols and narratives. Here, conceptualized aesthetics overshadows the sadness and the feeling of the "sense of certainty" of the past (the reflections of "mourning" come near the concept of "amnesia", as the lingering decadent phase of memory, the source of simulation ${ }^{27}$ ). The question arises if this is a return to the "linear" way of narrative expression and to the emphasis only on the past as historicity?

The crisis of lyricism in the arts is sometimes compared to the end of teleology: "... lyric poets today must face the task of forging their own single and consistent selves at a time when the concept of an individual subject is said to be an anachronism." ${ }^{28}$ We could consider a number of abstract artworks to be transformations of the romantic lyricism, which do not fit into any exact genre or stylistic definition, or into any form of narration. They either do not have or conceal a specific motif of loss, but do not deconstruct it: they demand a "transcendent experience" (painterly elegies by Franz Kline and Mark Rothko, image-word extensions by Cy Twombly, miniature suggestions by Olaf Christopher Jensen, to mention only a few). These are not necessarily abstractions, but rather extremely subjective images and expressions that postmodern

26 Th. Pfau, op. cit., pp. 559-562.

27 A. Huyssen, op. cit., p. 1.

28 P. H. Britto, Poetry and Memory. http://www.angelfire.com/ab6/phbritto/Poetry_and_Memory.pdf (date of access: June 2, 2020). 
measures cannot consolidate. Such figurativity seems to employ all the elements eliminated from postmodernism - energy, dynamics, mystery and spontaneity, as if nothing is meant to be consolidated and rationalized. Creative provisions of this kind are not manifestly declared: the painting form has no clear, unambiguous, stylistic descriptions; what is important is the creative process and the entirety that reveals itself from the perspective of time; rethinking the form rather than repeating the schemes and motives is most important. The new manifestations of Romanticism very often also seem to be too miniature and unsustainable - as if they are short-termed, partial, passive and thus do not translate into a movement that has any stronger impact. Characteristically, in the case of each contemporary artist, the content of memory seems to require a fundamentally different and new discussion. Not only because that revelation of the artist is always a kind of a cipher code, but also because the very tradition of Romanticism is re-recognized each time.

\section{Conclusion}

The theoretical concept of romantic memory is fundamentally controversial, so attempts have been made to reconstruct it by linking the insights of different authors. The highlighting of the romantic approach cannot partially escape the "structuring" inherent in contemporary contemplation of memory; however, in doing so, the intention was to reflect on nuances that do not obey such a strategy. We can get the impression that memory is just a variety of imagination which Romantics exalted. Looking back at Romantics, we can see that next to the transcendental nature of the images of consciousness, the so-called "moral imperative" that they emphasized is truly important. This permeated the pictorial representation with specific romantic sentimentalism, elegiac moods or a struggle with their inertia. Paradoxically, a romantic work ("poetic image") distinguishes memory from the non-narrative structure of images, when representation simply acts as memory (a revision of various experiences, sights and reflections).

How does a painterly image still preserve the "experience of historicity"? The answer to this question becomes clear when one compares the romantic and post-romantic perspective on the past. It seems that Romantics perceive the past as "not yet fulfilled", the image remains figuratively free and unpredictable, and occurs as an act of individualization. This can neither be replaced by the acts of "privatization" or "personalization" that act as "small narratives", as it has already been discussed, nor by the maintenance of a state of total nostalgia which conditionally reproduces a "lost reality" by changing it into a "cultural field". 
The identity of memory and historicity preserves the proper meaning of the activity for the artist. From the romantic point of view, both the internal and external translation of meanings, which cover the viewer's reactions and the whole meaningful communication field of the work of art, are important. A creator-Romantic, who usually trusts their eyesight, is seemingly a prophet and one who enjoys their creative freedom, but actually experiences constant strain. A premonition of certainty that is provided by the power of memory serves as a consciously accepted task for them. All the more so as creativity usually means to them an aspiration to transmit and continue ideals, as well as to confirm their own story and biography which is being discovered and decoded in such a manner. Thus, the symbolic form that is being created by them surpasses their personal experience and expresses a human aspiration - an effort to preserve individual memory.

\section{BIBLIOGRAPHY:}

Ankersmit Franklin Rudolf (2001) Historical Representation, Stanford: Stanford University Press.

Béguin Albert (1991) L’Âme romantique et le Rêve, Paris: José Corti.

Britto Paulo Henriques (2000) Poetry and Memory, transl. P. H. Britto. http://www.angelfire. com/ab6/phbritto/Poetry_and_Memory.pdf

Ferguson Frances (1996) Romantic Memory, "Studies in Romanticism" Vol. 35, No. 4, Winter, pp. 509-533.

Huyssen Andreas (1995) Twilight Memories. Making Time in a Culture of Amnesia, London: Routledge.

Klein Kerwin Lee (2000) On the Emergence of Memory in Historical Discourse, "Representations" (Special Issue: "Grounds for Remembering") No. 69, Winter, pp. 127-150.

Langer Susanne Knauth (1953) Feeling and Form. A Theory of Art, New York: Charles Scribner's Sons.

Lyotard Jean-François (1991) The Inhuman. Reflections on Time, transl. G. Bennington, R. Bowbly, Cambridge: Polity Press.

Pfau Thomas (2010) Mourning Modernity: Classical Antiquity, Romantic Theory, and Elegiac Form, "The Oxford Handbook of the Elegy", ed. K. Weisman, Oxford: Oxford University Press, pp. 546-564.

Schlegel Friedrich (1971) Friedrich Schlegel's Lucinde and the Fragments, transl. P. Firchow, Minneapolis: Minnesota University Press. 
Trybuś Krzysztof (2007), Biografia romantyczna jako forma pamięci, "Biografie romantycznych poetów”, ed. Z. Trojanowiczowa, J. Borowczyk, Poznań: Wydawnictwo Poznańskiego Towarzystwa Przyjaciół Nauk.

\section{MALARZ JAKO PROROK ZWRÓCONY KU PRZESZŁOŚCI (streszczenie)}

Przedmiotem artykułu jest problem rozpoznania romantycznego modelu pamięci we współczesnej sztuce wyłoniony w wyniku tzw. „Zwrotu narracyjnego” we współczesnej filozofii. Dwuznaczne filozoficzne twierdzenie Fryderyka Schlegela jest traktowane jako podstawowy zwrot analizy. Odsłania to charakter wizji i ambicji artysty (malarza) powszechnych na początku XIX wieku. Uwypuklenie mocy wspomnienia w procesie twórczości romantycznej wymagało, aby pamięć stała się głównym celem wyrazu artystycznego. Na tym polegają także współczesne strategie artystyczne. Opowieści wyobrażeniowe i subiektywne mity przemawiają biernymi obrazami i przenośniami. Czy stanowią one uporanie się z romantycznym zamiarem, czy jedynie jego dalszym ciągiem? Niniejsza analiza oparta na spostrzeżeniach Andreasa Huyssena, Franklina Rudolfa Ankersmita oraz innych badaczy stanowi próbę dotknięcia zagadnienia ogromnej transformacji pojęcia pamięci. Podkreśla się w niej, że obok bardzo spsychologizowanej wersji pamięci istnieją ważne nieprzybliżone aspekty tkwiące $\mathrm{w}$ filozoficzno-teologicznych interpretacjach romantyzmu. Aspekty te nie pozwalają sprowadzić pamięci do „wątku” lub „przedmiotu” w procesie twórczym. Autorka artykułu podkreśla wpływ mocy pamięci na tworzenie formy malarskiej i wewnętrzne przewidywanie znaczeń. Bez tego pozytywnego i zidealizowanego pojęcia pamięci (podkreślonego w filozofii romantycznej) forma malarska straciłaby swoją unikalność.

Słowa kluczowe: romantyzm, postromantyzm, pamięć, reprezentacja, narracja, malarstwo.

Agnè Kulbytė - PhD, lecturer at Vilnius Academy of Arts, Painting Department. She has an MA degree in Painting (2003) and a BA degree in Art (2007) from Vilnius Academy of Arts; between 2009 and 2013, she completed her doctoral studies in Philosophy at the Lithuanian Culture Research Institute in Vilnius (subject of the dissertation: "Romanticism as the Source of Postmodern Aesthetic Representation", 2014). Her field of research and publications are contemporary interpretations of romantic philosophy and aesthetics, modern and postmodern theories of art, abstract painting. 